\title{
Pengaruh Variasi Tinggi Lift, Lobe Separation Angle Camshaft, dan Roller Rocker Arm Terhadap Unjuk Kerja Motor Bensin Empat Langkah
}

\author{
H. Khairul Muhajir ${ }^{1}$ \\ Institut Sains \& Teknologi AKPRIND Yogyakarta \\ e-mail: khairul@ akprind.ac.id \\ A. A. P. Susastriawan ${ }^{2}$ \\ Institut Sains \& Teknologi AKPRIND Yogyakarta \\ Muh. H. Nur Aziz ${ }^{3}$ \\ Institut Sains \& Teknologi AKPRIND Yogyakarta \\ P. T. D. Rompas ${ }^{4}$ \\ Universitas Negeri Manado
}

\begin{abstract}
ABSTRAK
Salah satu cara untuk meningkatkan unjuk kerja motor bensin empat langkah adalah dengan memodifikasi camshaft. Memodifikasi camshaft bertujuan untuk mengatur waktu pembukaan katup (valve open), tinggi pembukaan katup (valve lift), dan mengatur jarak puncak pembukaan katup (lobe separation angle). Penambahan roller rocker arm juga dapat berpengaruh terhadap unjuk kerja mesin yang membuat camshaft berputar dengan gesekan yang lebih kecil. Tujuan dari penelitian ini adalah mengetahui pengaruh tinggi lift katup, lobe separation angle camshaft, dan roller rocker arm terhadap unjuk kerja motor bensin empat langkah. Dari hasil pengujian dynotest menunjukkan camshaft standar menghasilkan daya maksimal sebesar 13,6 HP dan torsi maksimal sebesar 13,7 N.m. camshaft modifikasi menghasilkan daya maksimal sebesar 13,8 HP dan torsi maksimal 11,59 N.m. camshaft modifikasi + roller rocker arm menghasilkan daya maksimal sebesar 14,6 HP dan torsi maksimal sebesar 12,75 N.m.Camshaft standar menghasilkan nilai sfc terendah sebesar 0,16141 $\mathrm{kg} / \mathrm{kW}$.jam. Camshaft modifikasi sebesar 0,20088 kg/kW.jam. Camshaft modifikasi + roller rocker arm sebesar $0,18098 \mathrm{~kg} / \mathrm{kW}$.jam.Pada pengujian emisi gas buang menunjukkan camshaft modifikasi + roller rocker arm menghasilkan kadar emisi yang paling ramah lingkungan.
\end{abstract}

Kata kunci: Camshaft, Lift, Lobe Separation Angle, Roller Rocker Arm, Valve

\begin{abstract}
One way to improve the performance of a four-stroke gasoline motor is to modify the camshaft. Modifying the camshaft aims to set the valve opening time, valve lift height, and adjust the lobe separation angle distance. The addition of roller rocker arm can also affect the performance of the engine that makes the camshaft rotate with smaller friction. The purpose of this research is to know the influence of high valve lift, lobe separation angle camshaft, and roller rocker arm to the performance of four-step gasoline motor. From the dynotest test results showed the standard camshaft produces a maximum power of $13.6 \mathrm{HP}$ and a maximum torque of 13.7 N.m. camshaft modifications generate maximum power of $13.8 \mathrm{HP}$ and maximum torque of 11.59 N.m. modification camshaft + roller rocker arm produces maximum power of 14.6 HP and maximum torque of 12.75 N.m. Standard chamshaft produces the lowest sfc value of $0.16141 \mathrm{~kg} / \mathrm{kW}$.jam. Camshaft modification of $0.20088 \mathrm{~kg} / \mathrm{kW} . j a \mathrm{~m}$. Camshaft + roller rocker arm modification of $0.18098 \mathrm{~kg} / \mathrm{kW} . j a m . I n$ the exhaust emissions
\end{abstract}

Jurnal Frontiers Volume 1 Nomor 1, April $2018 \quad 7$

P-ISSN: 2621-0991 E-ISSN: 2621-1009 
H. K. Muhajir ${ }^{1}$, A. A. P. Susastriawan², Jurnal Sains dan Teknologi, Universitas Negeri Manado M.H. N. Aziz ${ }^{3}$ \& P. T. D. Rompas 4

test shows the modified + roller rocker arm camshaft produces the most environmentally

friendly emission levels.

\section{Keyword: Camshaft, Lift, Lobe Separation Angle, Roller Rocker Arm, Valve}

\section{PENDAHULUAN}

Tingginya minat masyarakat terhadap kendaraan yang diiringi dengan pesatnya perkembangan ilmu pengetahuan dan teknologi membuat mereka semakin berusaha memenuhi kepuasan yang diinginkan. Para pengendara belum puas dengan kendaraan standar yang dikeluarkan oleh pabrikan kendaraan, sehingga rekayasa bidang otomotif dilakukan untuk meningkatkan kerja sebuah kendaraan dengan merubah sistem kerja standar pabrikan atau dengan merubah spesifikasi komponennya.

Salah satu cara untuk mendapatkan unjuk kerja yang baik adalah dengan mengatur debit bahan bakar yang masuk dan gas buang yang keluar ruang bakar oleh durasi dan lift dari camshaft . Camshaft (istilah bengkel : noken as) merupakan salah satu mekanisme penggerak katup (valve). Di dalam motor empat langkah terdiri dari dua jenis katup, yaitu katup hisap (intake valve) dan katup buang (exhaust valve). Katup hisap berfungsi untuk mengatur aliran campuran udara dan bahan bakar masuk ke dalam silinder motor, sedangkan katup buang berfungsi untuk mengatur aliran gas buang keluar dari silinder motor. Katup membuka dan menutup masing-masing satu kali setiap satu putaran camshaft dan dua kali putaran poros engkol (crankshaft). Pada sebuah camshaft terdapat bagian yang masing-masing mempunyai peranan penting. Bagianbagian camshaft seperti Valve lift (jarak angkat katup), valve lift duration (lama angkat katup), valve lift timing (waktu angkat katup), lobe separation angle (LSA) dan overlap akan mempengaruhi banyak sedikitnya campuran bahan bakar dan udara yang masuk kedalam ruang bakar. Berdasarkan latar belakang tersebut, maka penulis bermaksud melakukan penelitian dengan judul pengaruh variasi tinggi lift, lobe separation angle camshaft, dan roller rocker arm terhadap unjuk kerja motor bensin empat langkah.

\section{Valve Timing Diagram}

Pada motor 4 langkah valve timing berpengaruh terhadap proses kompresi di dalam silinder, yang akhirnya juga berpengaruh pada unjuk kerja motor itu sendiri. Diagram dibawah menunjukkan waktu pembukaan dan penutupan katup pada motor bensin.

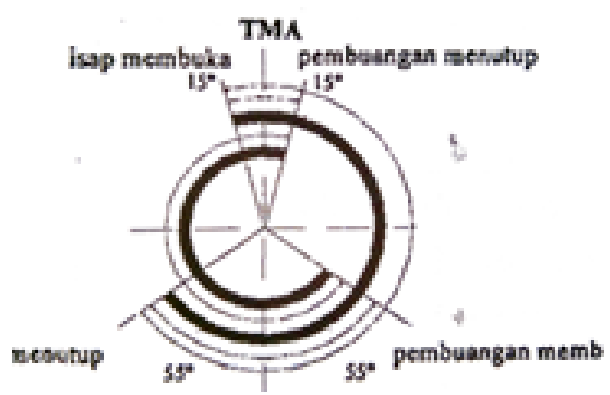

Gambar 1. Diagram Pembukaan dan

Penutupan Katup (Arends H.

Berenschot, 1980:186)

Pada motor bensin empat langkah, bahan bakar masuk ke ruang silinder setelah dicampur dengan udara di karburator. Pemasukan bahan bakar diatur oleh mekanisme katup dan camshaft. Katup in akan membuka beberapa derajat sebelum piston mencapai titik mati atas (TMA) dan menutup beberapa derajat setelah piston mencapai titik mati bawah (TMB). Katup ex akan membuka setelah terjadi proses pembakaran tepatnya 
beberapa derajat sebelum piston mencapai TMB dan menutup beberapa derajat setelah piston mencapai TMA.

Waktu pembukaan katup ditentukan dari profil camshaft. Camshaft berputar dan menekan katup sehingga katup membuka. Camshaft dihubungkan dengan poros engkol oleh rantai timing sehingga ketika poros engkol berputar dua kali camshaft ikut berputar satu kali.

Dalam desain sebuah camshaft terdapat berbagai bagian yang memiliki fungsi sendiri-sendiri yang akan mempengaruhi variasi buka-tutup dari katup masuk dan buang. Bagian-bagian dari camshaft dapat dilihat pada gambar 2

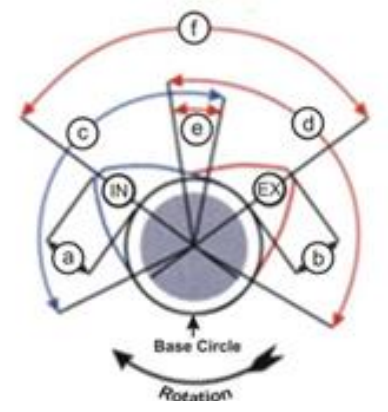

Keterangan Gambar :
a. Intake lobe Lift
b. Exhaust Lobe Lift
c. Intake Duration
d. Exhaust Duration
e. Overlap
f. Lobe Separation Angle (LSA)

Gambar 2. Bagian-bagian Camshaft (Yoyok, 2012)

Dalam sebuah desain camshaft baik itu intake lobe maupun exhaust lobe pasti memiliki puncak masing-masing. Puncak dari lobe tersebut disebut lobe center. Puncak dari intake lobe disebut juga dengan intake lobe centerline dan puncak dari exhaust lobe disebut juga exhaust lobe centerline. Jarak pemisah antara kedua lobe disebut lobe separation, karena diukur dalam derajat maka disebut lobe separation angle (sudut pemisah lobe).
Lobe separation angle (LSA) disebut juga jarak dalam derajat putaran camshaft antara intake lobe centerline dan exhaust lobe centerline.

Camshaft menggerakkan katup melalui rocker arm atau templar, pelatuk katup pada motor berfungsi sebagai penghubung antara camshaft dengan valve sebagai pengatur naik turunnya (bukatutup) katup. Rocker arm harus dibuat dengan kepresisian yang tinggi dan menggunakan material yang tepat sehingga dapat membuat pergerakan antara camshaft dan valve lebih presisi, sehingga supply bahan bakar dari karburator ke ruang bakar menjadi efisien.

Cara kerja dari Rocker arm digerakkan oleh camshaft sehingga dapat menekan valve dengan sempurna. Pergerakan rocker arm oleh camshaft terjadi karena pergesekan/benturan antara permukaan camshaft dengan permukaan rocker arm.

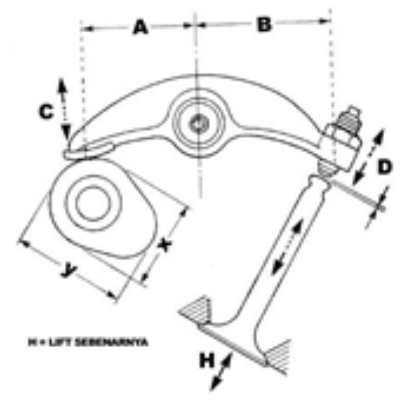

Gambar 3. Mekanisme Rocker Arm

Pada roller rocker arm tidak jauh berbeda dengan rocker arm pada umumnya, yang membedakan hanya terdapat roller atau bantalan gelinding yang dapat berputar saat terjadi gesekan dengan camshaft . Hal ini diharapkan dapat memperkecil kerugian gesekan yang terjadi dan membantu meningkatkan unjuk kerja pada sepeda motor tersebut. 


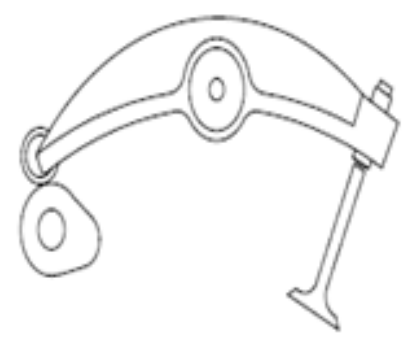

Gambar 4. Mekanisme Roller Rocker Arm

Berdasarkan latar belakang yang telah dikemukakan diatas, maka penelitian ini bertujuan untuk untuk mengetahui pengaruh variasi tinggi lift, lobe separation angle camshaft, dan roller rocker arm terhadap unjuk kerja motor bensin empat langkah.

\section{METODE}

\section{Diagram Alir Penelitian}

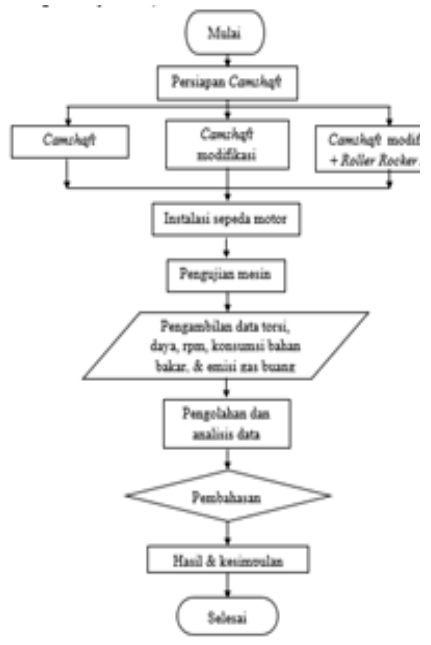

Gambar 5. Diagram alir penelitian

\section{Bahan Penelitian}

camshaft yang digunakan pada penelitian ini terdiri dari tiga buah camshaft yaitu camshaft standar sepeda motor mega pro, camshaft modifikasi, dan camshaft modifikasi dengan roller rocker arm.

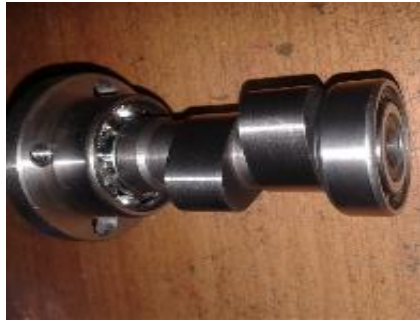

Gambar 6. camshaft modifikasi

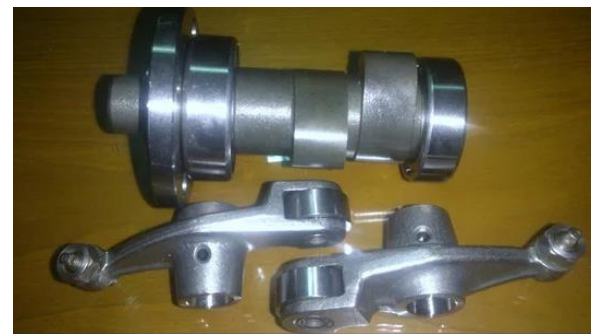

Gambar 7. Camshaft modifikasi + roller rocker arm

Tabel 1. Spesifikasi Camshaft

\begin{tabular}{|c|c|c|c|c|}
\hline No & Tipe Camshaft & Standar & Modifikasi & $\begin{array}{l}\text { Modifikasi + } \\
\text { roller rocker arm }\end{array}$ \\
\hline 1 & In Lift & $6,6 \mathrm{~mm}$ & $7,6 \mathrm{~mm}$ & $7,6 \mathrm{~mm}$ \\
\hline 2 & Ex Lift & $6,45 \mathrm{~mm}$ & $7,45 \mathrm{~mm}$ & $7,45 \mathrm{~mm}$ \\
\hline 3 & LSA & $96,25^{\circ}$ & $111,75^{\circ}$ & $111,75^{\circ}$ \\
\hline 4 & Durasi in & $260^{\circ}$ & $260^{\circ}$ & $260^{\circ}$ \\
\hline 5 & Durasi ex & $265^{\circ}$ & $265^{\circ}$ & $265^{\circ}$ \\
\hline 6 & $\begin{array}{c}\text { Katup masuk } \\
\text { (valve lift at } \\
1 \mathrm{~mm} \text { ) }\end{array}$ & $\begin{array}{c}\text { Buka : } 5^{\circ} \\
\text { sebelum TMA } \\
\text { Tutup : } 75^{\circ} \\
\text { getelah TMB }\end{array}$ & $\begin{array}{c}\text { Buka : } 6^{\circ} \text { setelah } \\
\text { TMA } \\
\text { Tutup : } 86^{\circ} \\
\text { setelah TMB }\end{array}$ & $\begin{array}{c}\text { Buka : } 6^{\circ} \text { setelah } \\
\text { TMA } \\
\text { Tutup : } 86^{\circ} \\
\text { setelah TMB }\end{array}$ \\
\hline 7 & $\begin{array}{l}\text { Katup buang } \\
\text { (valve lift at } \\
1 \mathrm{~mm} \text { ) }\end{array}$ & $\begin{array}{c}\text { Buka : } 20^{\circ} \\
\text { sebelum TMB } \\
\text { Tutup : } 65^{\circ} \\
\text { setelah TMA }\end{array}$ & $\begin{array}{c}\text { Buka : } 40^{\circ} \\
\text { sebelum TMB } \\
\text { Tutup : } 45^{\circ} \\
\text { setelah TMA }\end{array}$ & $\begin{array}{c}\text { Buka : } 40^{\circ} \\
\text { sebelum TMB } \\
\text { Tutup : } 45^{\circ} \\
\text { setelah TMA }\end{array}$ \\
\hline
\end{tabular}

\section{Setup Pengujian}

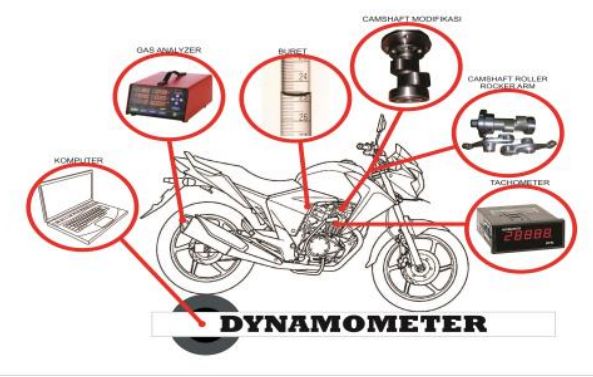

Gambar 8. Setup pengujian 
H. K. Muhajir ${ }^{1}$, A. A. P. Susastriawan², Jurnal Sains dan Teknologi, Universitas Negeri Manado M.H. N. Aziz ${ }^{3}$ \& P. T. D. Rompas 4

Tabel 2. Pengkodean camshaft

\begin{tabular}{|c|c|c|c|c|}
\hline Kode Camshaft & Jenis Camshuft & LSA & In.Lift & ExLLift \\
\hline Cl & Standar & $96,25^{\circ 1}$ & $6,6 \mathrm{~mm}$ & $6,45 \mathrm{~mm}$ \\
\hline C2 & Modifikasi & $111,75^{\circ}$ & $7,6 \mathrm{~mm}$ & $7,45 \mathrm{~mm}$ \\
\hline C3 & $\begin{array}{c}\text { Modifikasi + roller } \\
\text { rocker arm }\end{array}$ & $111,75^{\circ}$ & $7,6 \mathrm{~mm}$ & $7,45 \mathrm{~mm}$ \\
\hline
\end{tabular}

HASIL DAN PEMBAHASAN

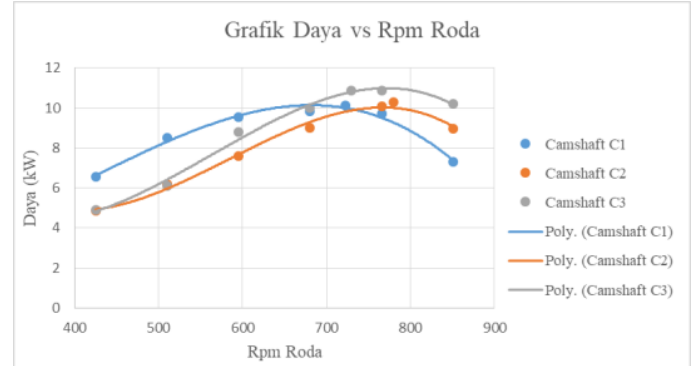

Gambar 9. Grafik daya pada ketiga jenis camshaft

Berdasarkan grafik hasil pengujian pada gambar 9 menunjukkan adanya perubahan daya pada tiap-tiap camshaft . Perubahan daya merujuk ke arah kenaikan daya yang dihasilkan dengan memodifikasi camshaft . Untuk mempermudah dalam menganalisa, pembahasan dibagi menjadi dua kelompok putaran roda.

a. Putaran roda 400-600 rpm.

Pada camshaft C1 kenaikan daya cenderung kecil, pada putaran ini daya yang dihasilkan lebih tinggi dibandingkan dengan kedua jenis camshaft yang lainnya. Hal ini dikarenakan camshaft $\mathrm{C} 1$ memiliki LSA (lobe separation angle) yang lebih sempit $\left(96,25^{\circ}\right)$ dibandingkan LSA camshaft C2 dan C3 $\left(111,75^{\circ}\right)$. Pada camshaft C1 katup hisap membuka lebih cepat $5^{\circ}$ sebelum TMA dan katup buang menutup $65^{\circ}$ setelah TMA, Ketika piston mencapai TMA dan akan melakukan langkah hisap, katup hisap sudah membuka $5^{\circ}$ sebelum TMA. Dibanding dengan camshaft C2 dan C3 katup hisap membuka $6^{\circ}$ setelah TMA dan katup buang menutup $45^{\circ}$ setelah TMA. Hal ini memberikan keuntungan yang baik pada putaran rendah karena pemasukan bahan bakar lebih cepat sehingga daya yang dihasilkan pun lebih tinggi dibanding kedua jenis camshaft yang lainnya.

b. Putaran roda 600-850 rpm.

Pada putaran roda 600 - 800 rpm daya yang dihasilkan dari ketiga jenis camshaft mengalami perubahan. Pada camshaft $\mathrm{C} 1$ daya yang dihasilkan tidak mengalami kenaikan yang tinggi, bahkan mengalami penurunan daya yang lebih cepat pada putaran 765,4 rpm. Daya maksimal yang dihasilkan sebesar $10,14 \mathrm{~kW}$ pada putaran roda $722 \mathrm{rpm}$.

Pada camshaft C2 terjadi kenaikan daya yang tinggi sebesar $2,7 \mathrm{~kW}$, daya maksimal yang dihasilkan sebesar 10, $14 \mathrm{~kW}$. hal ini dikarenakan camshaft C2 memiliki tinggi katup in $1 \mathrm{~mm}$ lebih tinggi dari tinggi katup in camshaft $\mathrm{C} 1$ dan katup ex juga lebih tinggi $1 \mathrm{~mm}$ dari katup ex camshaft C1. Hal ini menyebabkan jumlah campuran bahan bakar yang masuk lebih banyak dan menghasilkan tekanan kompresi yang lebih tinggi dibandingkan camshaft $\mathrm{C} 1$.

Sedangkan pada camshaft C3 daya yang dihasilkan lebih tinggi dibandingkan kedua jenis camshaft lainnya. Hal ini dikarenakan pada camshaft C3 menggunakan roller rocker arm yang berputar saat bersentuhan dengan camshaft sehingga gesekan yang terjadi lebih kecil dan mesin dapat berputar secara optimal. Daya maksimal yang dihasilkan sebesar 10,88 $\mathrm{kW}$ pada putaran roda 729,7 rpm. Setelah mencapai daya maksimal, tidak terjadi penurunan daya yang besar dibanding kedua jenis camshaft lainnya. 


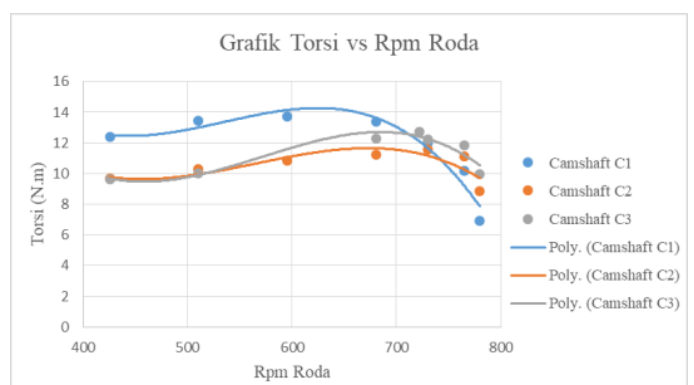

Gambar 10. Grafik torsi pada ketiga jenis camshaft

Berdasarkan grafik pada gambar 10 menunjukan perbedaan torsi yang dihasilkan dari ketiga jenis camshaft . Torsi tertinggi dihasilkan oleh camshaft C1 yaitu sebesar 13,7 N.m pada putaran roda 595,3 rpm. Setelah mencapai torsi maksimal pada putaran yang lebih tinggi torsi mengalami penurunan yang signifikan. Torsi pada camshaft $\mathrm{C} 2$ dan C3 lebih kecil dibandingkan dengan camshaft $\mathrm{C} 1$ hal ini dikarenakan pada katup ex camshaft C2 dan C3 membuka pada $40^{\circ}$ sebelum TMB, sehingga tekanan pembakaran pada ruang bakar berkurang sebelum piston mencapai TMB. Torsi maksimal yang dihasilkan camshaft $\mathrm{C} 2$ sebesar 11,59 N.m pada putaran roda 729,7 rpm. Pada camshaft C3 torsi maksimal yang dihasilkan 12,75 rpm pada putaran roda 722 rpm. Terjadi kenaikan torsi yang signifikan pada putaran roda 500 - $700 \mathrm{rpm}$, hal ini dikarenakan pengaruh roller rocker arm yang mengurangi gesekan pada putaran mesin tinggi sehingga mesin dapat bekerja secara optimal.

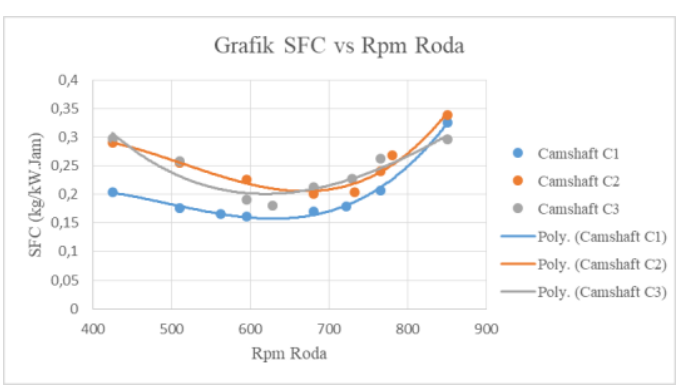

Gambar 11. Grafik sfe pada ketiga camshaft
Berdasarkan grafik hasil pengujian pada gambar 11 Menunjukkan adanya perbedaan konsumsi bahan bakar spesifik pada masing-masing jenis camshaft . Semakin tinggi putaran roda nilai konsumsi bahan bakar spesifik belum tentu semakin tinggi pula. Tinggi rendahnya nilai konsumsi bahan bakar spesifik tergantung dari besarnya daya yang dihasilkan. Pada camshaft C1 memiliki nilai konsumsi bahan bakar spesifik yang paling rendah diantara dua jenis camshaft yang lainnya. Hal ini dikarenakan nilai laju konsumsi bahan bakar yang lebih rendah dikarenakan perbedaan tinggi katup yang lebih rendah pula sehingga volume campuran bahan bakar dan udara yang terhisap masuk kedalam ruang bakar pun lebih sedikit dibanding dua jenis camshaft lainnya. Nilai konsumsi bahan bakar terendah camshaft C1 sebesar $0,16141 \mathrm{~kg} / \mathrm{kW}$.jam pada putaran roda 595,3 rpm. Pada camshaft $\mathrm{C} 2$ terjadi penurunan nilai konsumsi bahan bakar spesifik secara stabil sejalan dengan kenaikan daya yang terjadi. Nilai konsumsi bahan bakar spesifik terendah sebesar 0,20088 $\mathrm{kg} / \mathrm{kW}$.jam pada 680,4 rpm. Pada camshaft $\mathrm{C} 3$ nilai konsumsi bahan bakar spesifik terendah sebesar 0,18098 $\mathrm{kg} / \mathrm{kW}$.jam pada putaran roda $628,5 \mathrm{rpm}$. Setelah melewati nilai konsumsi bahan bakar spesifik terendah, nilai konsumsi bahan bakar spesifik kembali naik. Hal ini dikarenakan pada putaran yang semakin tinggi thorttle valve terbuka lebih lebar yang menyebabkan campuran bahan bakar dan udara yang masuk ke ruang bakar semakin besar.

Perbedaan nilai SFC yang terjadi pada camshaft $\mathrm{C} 1, \mathrm{C} 2$ dan $\mathrm{C} 3$ dipengaruhi oleh dua faktor, yaitu nilai laju konsumsi bahan bakar spesifik dan daya yang dihasilkan. 
Emisi gas buang $\mathrm{CO}_{2}$

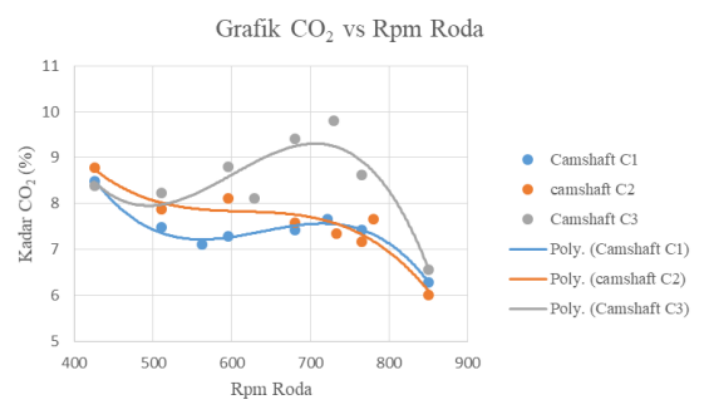

Gambar 12. Grafik kadar $\mathrm{CO}_{2}$ vs rpm roda.

Gas buang $\mathrm{CO}_{2}$ atau karbon dioksida merupakan hasil dari pembakaran sempurna hidro karbon dari bahan bakar minyak bumi atau gas alam. Semakin tinggi kadar $\mathrm{CO}_{2}$ berarti proses pembakaran yang terjadi semakin sempurna dan jumlah udara lebih dari cukup. Berdasarkan grafik pada gambar 12 menunjukkan bahwa kadar $\mathrm{CO}_{2}$ semakin rendah seiring dengan putaran roda yang semakin tinggi. Namun saat mencapai rpm torsi dan daya maksimal, kadar $\mathrm{CO}_{2}$ cenderung stabil bahkan mengalami kenaikan. Hal ini menunjukkan bahwa pembakaran yang sempurna menghasilkan torsi dan daya yang tinggi.

Emisi gas buang $\mathrm{CO}$

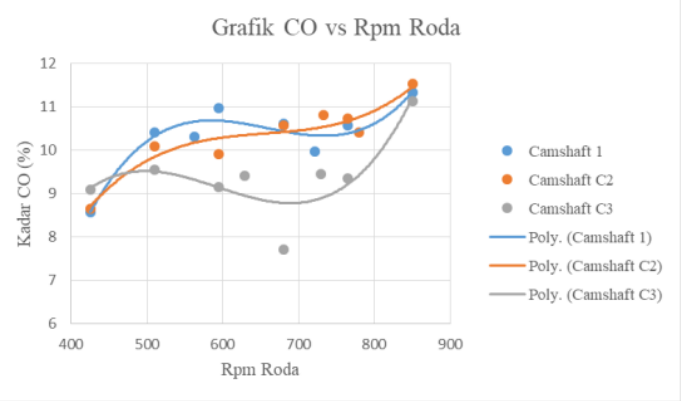

Gambar 13. Grafik CO vs rpm roda

Emisi gas $\mathrm{CO}$ atau karbon monoksida adalah gas yang timbul karena reaksi pembakaran yang tidak sempurna. Hal ini dikarenakan jumlah oksigen yang tidak mencukupi atau bisa juga disebabkan oleh proses pencampuran bahan bakar yang tidak sempurna. Berdasarkan grafik pada gambar 13 menunjukkan semakin tinggi putaran roda kadar $\mathrm{CO}$ juga semakin tinggi. Namun, pada rentan rpm torsi dan daya maksimal kadar CO senderung stabil bahkan mengalami penurunan. Pada rpm yang lebih tinggi kadar $\mathrm{CO}$ kembali meningkat. Hal ini sejalan dengan grafik $\mathrm{CO}_{2}$ pada gambar 4.4 yang menunjukkan semakin tinggi putaran roda maka kadar $\mathrm{CO}_{2}$ semakin rendah yang disebabkan karena reaksi pembakaran yang tidak sempurna.

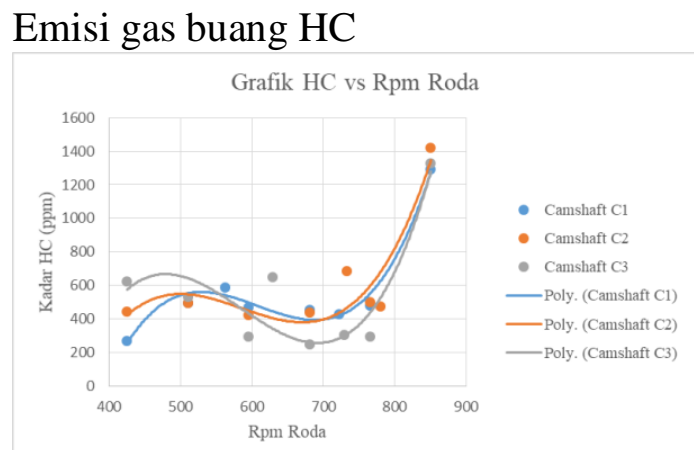

Gambar 14. Grafik kadar HC vs rpm roda

HC atau hidro karbon adalah gas buang yang diakibatkan karena bahan bakar yang tidak terbakar. HC adalah bagian dari bahan bakar yang dilepaskan baik dalam bentuk tidak terbakar atau tidak terpecah dengan sempurna. Hal ini bisa disebabkan karena kurangnya oksigen, suhu pembakaran yang turun, ataupun rendahnya kandungan oktan bahan bakar yang menyebabkan bahan bakar sulit terbakar dengan sempurna. Berdasarkan grafik HC pada gambar 14 kadar HC cenderung stabil pada putaran roda 400-750 rpm. Pada putaran roda diatas $750 \mathrm{rpm}$ kadar $\mathrm{HC}$ meningkat drastis, hal ini disebabkan karena putaran mesin yang sangat tinggi menyebabkan proses pembakaran yang terjadi sangat cepat sehingga bahan bakar belum sempat terbakar seluruhnya. 


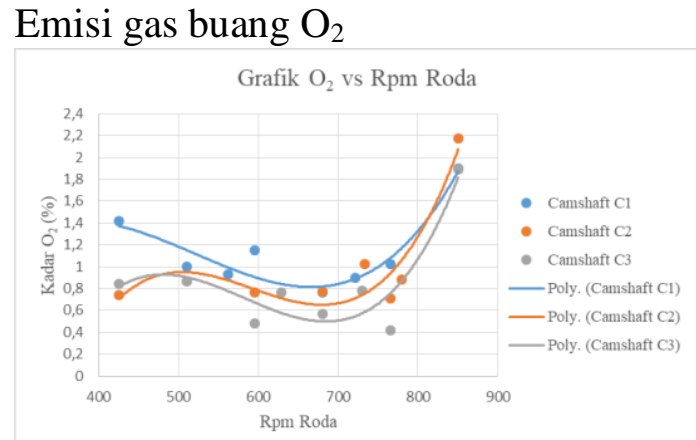

Gambar 15. Grafik kadar $\mathrm{O}_{2}$ vs rpm roda

Emisi gas buang $\mathrm{O}_{2}$ adalah sisa oksigen dari proses pembakaran bahan bakar yang disebabkan karena proses pembakaran yang tidak sempurna, pasokan udara yang berlebih, atau bisa juga disebabkan karena bahan bakar yang terlalu sedikit. Berdasarkan grafik pada gambar 4.7 kadar $\mathrm{O}_{2}$ cenderung menurun saat mendekati rpm daya dan torsi maksimal, hal ini menunjukkan bahwa proses pembakaran yang terjadi sempurna. Pada putaran tinggi kadar $\mathrm{O}_{2}$ mengalami kenaikan yang signifikan. Hal ini disebabkan karena pada putaran mesin yang tinggi proses pembakaran terjadi sangat cepat sehingga campuran bahan bakar dan udara tidak bisa terbakar secara sempurna.

\section{PENUTUP}

\section{Kesimpulan}

Berdasarkan hasil penelitian pengaruh variasi tinggi lift, lobe separation angle camshaft, dan roller rocker arm terhadap unjuk kerja sepeda motor 4 langkah, memperoleh hasil sebagai berikut :

1. Daya maksimal yang dihasilkan camshaft C3 dengan menggunakan roller rocker arm lebih tinggi yaitu sebesar 14,6 HP pada putaran roda 729,7 rpm, dibanding camshaft C2 yang memiliki tinggi lift dan LSA yang sama hanya menghasilkan daya sebesar 13,8 HP pada putaran roda 779,8 rpm. Sedangkan camshaft standar C1 menghasilkan daya sebesar 13,6 HP pada putaran roda $722 \mathrm{rpm}$.

2. Torsi maksimal dihasilkan mesin dengan camshaft $\mathrm{C} 1$ (LSA 96,25 ) yaitu sebesar 13,7 N.m pada putaran roda 595,3 rpm. Pada camshaft C2 $\left(\right.$ LSA $111,75^{\circ}$ ) torsi maksimal sebesar 11,59 N.m pada putaran roda 729,7 rpm. Sedangkan pada camshaft C3 (LSA $111,75^{\circ}$ ) torsi maksimal sebesar 12,75 N.m padap putaran roda 722 rpm. Dapat disimpulkan bahwa LSA camshaft yang lebih sempit menghasilkan torsi yang lebih tinggi.

3. Nilai konsumsi bahan bakar spesifik terendah dihasilkan camshaft $\mathrm{C} 1$ yaitu sebesar $0,16141 \quad \mathrm{~kg} / \mathrm{kW}$.jam pada putaran roda 595,3 rpm. Pada camshaft C2 nilai konsumsi bahan bakar spesifik terendah sebesar $0,20088 \mathrm{~kg} / \mathrm{kW}$.jam pada putaran roda $680,4 \mathrm{rpm}$. Pada camshaft C3 nilai konsumsi bahan bakar spesifik terendah sebesar $0,18098 \mathrm{~kg} / \mathrm{kW}$.jam.

4. Hasil pengujian emisi gas buang menunjukkan bahwa camshaft $\mathrm{C} 3$ memiliki kadar $\mathrm{CO}, \mathrm{CO}_{2}, \mathrm{HC}$, dan $\mathrm{O}_{2}$ yang lebih baik dibanding dengan dua jenis camshaft t yang lainnya. Hal ini berarti camshaft C3 lebih ramah lingkungan.

\section{DAFTAR PUSTAKA}

Adi, Rian Wijanarko, (2013). Studi Eksperimental Tentang Pengaruh Variasi Camshaft Terhadap Kinerja Motor Empat Langkah $125 \mathrm{Cc}$ Penyalaan Bunga Api, Skripsi, UMY, Yogyakarta.

Apriana, Candra Andita., dkk., (2015). Desain Sistem Kelistrikan Sepeda Motor Sebagai Alat Bantu Ajar Mahasiswa, SEMINAR NASIONAL XI SDM TEKNOLOGI NUKLIR, YOGYAKARTA. 
H. K. Muhajir ${ }^{1}$, A. A. P. Susastriawan², Jurnal Sains dan Teknologi, Universitas Negeri Manado M.H. N. Aziz ${ }^{3}$ \& P. T. D. Rompas 4

Arends, BPM. \& Barenschot, H., Muarifudin, A., (2017). Unjuk Kerja (1980). Motor Bensin, Alih Bahasa : Umar Sukrisno, Penerbit Erlangga, Jakarta.

Aryadi, W., \& Karnowo., (2008). Motor Bensin, UNNES, Semarang.

Burgess, Peter, and Gollan, David, (2000). "How To Build, Modify And Power Tune Cylinder Head", Veloce Publishing PLC, United Kingdom

Cengel, A Yunus., and Dr. Boles, Michael A., (1994). "Thermodynamics An Engineering Approach Second Edition", USA : McGraw-Hill, Inc.

Daryanto., (2002). "Teknik Reparasi dan Perawatan Sepeda Motor", Buni Aksara, Jakarta.

Hartadi, Tri., (2015). Pengaruh Perubahan Lobe Separation Angle Terhadap Daya dan Torsi Pada Sepeda Motor Jupiter Z 110 Tahun 2007, Skripsi, Universitas Muhamadiyah Pontianak, Pontianak.

Heywood, J. B., (1989). "Internal Combustion Engine Fundamental", MC Graw-Hill Book Company, Singapore.

Hidayah, M. K.., (2012). Analisis Torsi dan Daya Akibat Pemotongan Ramp Poros Bubungan (Camshaft) pada Sepeda Motor Suzuki Shogun 125 SP Tahun 2005, UNS, Surakarta.

Honda Parts Catalogue Megapro, termuat di www.hondacengkareng.com, diakses tanggal 5 september 2017 pukul 19.00 .

Sepeda Motor 4 Langkah Fuel Injection terhadap Penggunaan Bahan Bakar Premium dan Pertalite, Skripsi, IST AKPRIND, Yogyakarta.

Muhajir, H. Khairul., (2009). "Motor Bakar Torak", AKPRIND PRESS., Yogyakarta.

Nathan, Stanley., (2012). Karakteristik Kinerja Mesin 4-Tak $100 \mathrm{Cc}$ pada 3 Konfigurasi Bukaan Katup Untuk Pengembangan Mekanisme Vvt Sohc, Skripsi, Universitas Indonesia, Depok.

Nanlohy, Hendry Yoshua, (2012). "Perbandingan Variasi Derajat Pengapian Terhadap Efisiensi Thermal dan Konsumsi Bahan Bakar Otto Engine BE50", DINAMIKA Jurnal Ilmiah Teknik mesin, vol. 3 No. 2, hlm 211-215.

Pamungkas, Yohanes Babtis., Pengaruh Camshaft Antara Camshaft Standar Dengan Camshaft Racing Terhadap Daya, Torsi, dan AFR (Air Fuel Ratio), Skripsi, Universitas Mercu Buana, Jakarta.

Prihardintama, Sakti., (2010). Pengaruh Variasi Durasi Noken As Terhadap Unjuk Kerja Mesin Honda Kharisma Dengan Menggunakan 2 Busi, Tugas Akhir, ITS, Surabaya.

Setiyo, M., \& Bagiyo, C. P., (2012). Pemajuan Valve Timing terhadap Peningkatan Perbandingan Kompresi Aktual Torsi dan Daya, Prosiding Seminar Nasional Sains dan Teknologi. Universitas Wahid Hasyim Semarang: A.34-A.39 . 
H. K. Muhajir ${ }^{1}$, A. A. P. Susastriawan², Jurnal Sains dan Teknologi, Universitas Negeri Manado

Sucipto, A., (2015). Pengaruh Tinggi Lift, Lobe Separation Angle Camshaft terhadap Unjuk Kerja Motor Bensin Empat Langkah, Skripsi, IST AKPRIND, Yogyakarta.

Sukidjo, FX., (2008). "Pengaruh Durasi Camshaft terhadap Konsumsi Bahan Bakar, Emisi Gas Buang, Torsi dan Daya Mesin pada Mesin Bensin", Forum Teknik., vol. 32, No. 3, hlm 214-220.

Sulistiono, E., (2004). Mekanisme dan Perawatan Sistem Bahan Bakar pada Yamaha Mio Tahun 2004, Tugas Akhir, UNNES, Semarang.

Utomo, A., (2007). Analisa Pengaruh Durasi Camshaft Terhadap Unjuk Kerja Motor Bakar Honda Supra X 125 Tune Up Road Race, Skripsi, Universitas Kristen Petra, Surabaya.

Yamaha "Genuine Part \& Accessories, Part catalogue 2PV8 2016", termuat di www.yamaha-motor.co.id, diakses tanggal 5 september 2017 pukul 19.30.

Yamaha "Genuine Part \& Accessories, Part catalogue 5TL3 2006", termuat di www.yamaha-motor.co.id, diakses tanggal 5 september 2017 pukul 19.40 .

Yulianto, E., (2008). Perbedaan Penggunaan Camshaft racing dan Camshaft Standar pada Tiap Putaran terhadap Daya dan Emisi Gas Buang pada Motor Honda Tiger 2000, Skripsi, UNM, Malang.

Yoshia, F., (2012). Analisa Pengaruh Perubahan Tinggi Bukaan Katup Terhadap Kinerja Motor bakar Otto,
Skripsi, Universitas Indonesia, Depok.

Yoyok, dkk. (2012). "Pengaruh Variasi Lobe Separation Angle Camshaft dan Variasi Putaran Mesin terhadap Daya Pada Sepeda Motor Honda Supra X 125 Tahun 2008", NOSEL, vol. 1, No. 1, hlm 98-105. 